\title{
Studi Analisis Penerjemahan Verba Berpreposisi pada Novel Terjemahan Alfu Lailah Wa Lailah Karya Fuad Syaifuddin Nur
}

\author{
Ima Nurmala, Syihabuddin, \& Asep Sopian \\ Pendidikan Bahasa Arab, Fakultas Pendidikan Bahasa dan Sastra \\ Universitas Pendidikan Indonesia \\ imanurmala30@student.upi.edu; syihabuddin@upi.edu; asepsopian@upi.edu
}

\begin{abstract}
How to cite (in APA Style): Nurmala, Syihabuddin, \& Sopian, A. (2019). Studi analisis penerjemahan verba berpreposisi pada novel terjemahan Alfu Lailab $W$ a Lailah karya Fuad Syaifuddin Nur. Jumal Pendidikan Babasa dan Sastra, 19(1), 131-137, doi: 10.17509/bs_jpbsp.v19i1.20765
\end{abstract}

Article History: Received (13 December 2018); Revised (13 February 2019); Accepted (1 April 2019)

Journal homepage: http://ejournal.upi.edu./index.php/BS_JPBSP

Abstrak: Penerjemahan dalam ruang lingkup bahasa memiliki peran penting bagi peradaban dunia. Penerjemahan merupakan proses penggantian teks suatu bahasa ke dalam bahasa lain (Catford, 1965). Penelitian ini menganalisis verba berpreposisi sebagai salah satu kolokasi dalam bahasa Arab untuk diteliti bentuk verba yang jatuh sebagai idiom dan non-idiom dan mendeskripsikan kecenderungan penerjemahannya pada novel terjemahan Alfu Lailah wa Lailah karya Fuad Syaifuddin Nur. Untuk mencapai tujuan tersebut, peneliti menggunakan metode penelitian kualitatif dengan pendekatan analisis konten. Berdasarkan hasil penelitian dari 43 data ditemukan 56 verba berpreposisi, 2 verba berpreposisi idiom dan 54 verba berpreposisi nonidiom. Adapun dari kecenderungan penerjemahan, ditemukan 22 penerjemahan setia, 7 penerjemahan semantis, 1 penerjemahan idiomatik, dan 13 penerjemahan komunikatif.

Kata kunci : idiom; penerjemahan; verba berpreposisi

\section{Translation Analysis of Prepositional Verbs on Novel Alfu Lailah Wa Lailah by Fuad Syaifuddin Nur}

\begin{abstract}
Translation in the scope of language has an important role for world civilization. Translation is the process of changing the text of one language into another language (Catford, 1965). This study analyzes prepositional verbs as one of the collocations in Arabic to examine the form of verbs as idioms and non-idioms and describes the tendency of translation in the novel translation of Alfu Lailah wa Lailah by Fuad Syaifuddin Nur. To achieve these objectives, researchers used qualitative research methods with a content analysis approach. Based on the research results from 43 data found 56 prepositional verbs, 2 prepositional verbs of idioms and 54 prepositional verbs of non-idioms. As for the tendency of translation, it was found 22 faithful translations, 7 semantic translations, 1 idiomatic translation, and 13 communicative translations.
\end{abstract} Keywords: idiom; translation; prepositional verbs 


\section{PENDAHULUAN}

Penerjemahan dalam ruang lingkup bahasa memiliki peran penting bagi peradaban dunia. Dalam Syihabuddin (2016, p. 1) catatan sejarah menegaskan bahwa peradaban Islam pertamatama berkembang melalui penerjemahan karyakaya lama Yunani, Persia, India, dan mesir dalam bidang ilmu eksasta dan kedokteran.

Penerjemahan menurut Catford (1965, p.. 1) process of substituting a text in one language for a text in another, yakni merupakan proses penggantian teks suatu bahasa ke dalam bahasa lain. Sedangkan dalam pandangan Dhyaningrum dkk (2016, p.2) bahwasannya menerjemahkan bukan sekedar mengalihbahasakan teks dari bahasa sumber ke bahasa sasaran, skill menerjemahkan yang baik juga tak lepas dari kemahiran penerjemah untuk mengalihkan makna dan unsur estetikanya.

Adapun yang dinamakan terjemahan yang baik menurut para ahli, seperti mana yang diungkapkan oleh Kamalie (2013, p.172) adalah yang tidak tampak bahwa ia adalah terjemahan. Ia menuturkan pula bahwa salah satu hal yang menyebabkan tidak sempurnanya terjemahan tersebut adalah kegagalan penerjemah dalam mengenali gabungan sejumlah unsur leksikal sebagai sebuah kolokasi. Hal ini senada dengan penuturan Perdana (2017, p.3) kolokasi merupakan objek yang sangat penting untuk dikaji dalam teknik menerjemahkan suatu bahasa, karena kolokasi merupakan suatu fenomena umum yang dimiliki oleh setiap bahasa yang memiliki karakteristik tertentu yang unik yang membedakan bahasa tersebut dengan bahasa lainnya. Adapun yang dimaksud dari kolokasi dalam hal ini merujuk pada pendapat Sa'ad dkk (2015, p.. 11) yaitu kombinasi dua atau lebih komponen perkataan dalam bahasa.

Pada penerjemahan teks yang bersumber dari teks berbahasa Arab, kajian kolokasi ini tak luput dari perhatian para peneliti. Di antaranya hal ini tercermin dari penelitian yang dilakukan oleh Kamalie (2013, p.143) yang melakukan penelitian tentang masalah penerjemahan kolokasi dalam Tafsir Fi Zilal al-Qur'an. Salah satu objek kajian dalam penelitian kolokasi tersebut adalah kolokasi frasa verba. Adapun yang dimaksud dengan frasa verbal seperti mana yang diungkapkan oleh Kamalie (2013, p.176) yaitu kolokasi berupa kombinasi dari verba dengan preposisi yang dalam bahasa Inggris dikenal dengan Phrasal Verbs atau dalam istilah linguistik Indonesia dinamakan dengan "verba berpreposisi". Berdasarkan hal tersebut dapat dipahami bahwa kajian verba berpreposisi (selanjutnya VBp) ini melibatkan dua unsur kalimat, yaitu verba dan preposisi.

Menurut Nur (2016, p.1) verba merupakan unsur inti atau 'umdah dalam bangun kalimat bahasa Arab selain unsur subjek itu sendiri. Dalam kalimat, sejumlah verba tidak bisa berdiri sendiri sebagai satuan yang bermakna melainkan harus didampingi oleh preposisi (ḥuñfu 'l-jar).

Adapun VBp bahasa Arab dari segi kajian ilmu semantik, menurut Aldahesh (2016, p.3) jatuh ke dalam dua jenis : idiom dan nonidiom. Ia menjelaskan pula bahwasanya yang dimaksud VBp idiom yaitu verba yang membentuk makna baru yang berbeda dari makna leksikal verba dan preposisi tersebut oleh sebab kehadiran preposisi yang menyertainya. Sebagai contoh yaitu verba amsaka, secara literal bermakna 'menahan', namun maknanya bisa berubah menjadi 'berhenti' ketika bergabung dengan preposisi 'an. Hal ini tercermin dari contoh ayat al-Quran : wa lisaanubaa laa yumsiku 'an al-tilaawati dan lisan mereka tak pernah berhenti membaca qur'an'. Sedangkan yang dimaksud dengan VBp non-idiom adalah kombinasi VBp yang masih mempertahankan makna leksikalnya. Salah satu contoh yaitu kombinasi VBp haraba min yang bermakna 'melarikan diri dari' dalam kalimat: wa abrubu an al-mawti'dan aku melarikan diri dari maut'.

Dikarenakan keterkaitannya yang sangat erat dengan ranah penerjemahan, maka penelitian ini akan difokuskan pada analisis metode penerjemahan verba berpreposisi pada terjemahan Novel Alfu Lailah wa Lailah karya Fuad Syaifuddin Nur.

Nur (2010) mengatakan bahwa buku "Seribu Satu Malam" adalah salah satu rujukan otentik terbaik tentang kehidupan nyata yang terdapat di dalam khazanah kesusastraan Arab yang mengandung banyak kisah dan hikayat yang dapat menjadi sumber pengetahuan untuk mengetahui sejarah masa silam. Tentu saja banyak faktor yang menyebabkan novel tanpa pengarang jelas ini diminati (laris) oleh pembaca Indonesia. Selain karena popularitas 
Nurmala, Syihabuddin, \& Sopian, Analisis penerjemahan verba berpreposisi...

novel yang sudah mendunia, faktor penerjemahan juga sangat berpengaruh terhadap minat pembaca.(Rokib \& Mudzakkir, 2016, p.2).

Dikarenakan keterbatasan waktu peneliti, pada penelitian kali ini dipilih salah satu judul kisah dari novel tersebut guna sebagai sampel untuk memfokuskan penelitian, yakni Kisah Raja Syarayar dan Raja Syahzaman. Hal ini didasarkan pula pada pra observasi peneliti menemukan adanya variasi penerjemahan dalam kalimat yang mengandung VBp dalam kisah tersebut. Temuan tersebut di antaranya adalah sebagai berikut :

قد خس قدري عندك حتى دخّلتَ عليَّ الرجال الأجانب

Mengapa ayah membuatku malu dengan membawa seorang pemuda asing ke hadapanku. (Nur, 2010, p.. 14)

Pada contoh data di atas terdapat VBp Menurut Ali (TT, p.. 884) secara leksikal VBp دخل + الم ل 'memasukkan + ke'. Namun dalam penerjemahan di atas VBp tersebut tidak diterjemahkan secara setia, yakni hanya muncul makna preposisi saja sedangkan makna verba mengalami pelesapan dari makna leksikalnya. Selain itu, perubahan struktur kalimat yang sangat kontras dan lebih cenderung pada bahasa sasaran menunjukkan bahwa penerjemah hanya menerjemahkan secara komunikatif.

Adapun di sisi lain terkadang penerjemah menggunakan penerjemahan setia dengan tetap mempertahankan makna leksikal VBp, seperti contoh berikut :

$$
\text { فرفعت رأسها إلى أعلى الثجرة }
$$

Gadis malang itu menegadabkan kepalanya ke atas pohon ( Nur, 2007, p.5)

Berdasarkan data di atas, terdapat VBp

رفع + إلى Secara leksikal VBp .رفع + إلى bermakna 'mengangkatkan+ ke atas'. Dalam terjemahan, VBp ini telah diterjemahkan dengan tetap memunculkan makna leksikal dari verba dan preposisi sesuai struktur bahasa sumber. Verba disepadankan pada bahasa sasaran sesuai konteks kalimat yaitu menjadi 'menengadahkan'. Hal ini menunjukkan bahwa penerjemah menggunakan makna secara setia.

Berdasarkan hal tersebut, Peneliti ingin mengetahui lebih lanjut bagaimana penerjemahan VBp bahasa Arab tersebut ke dalam bahasa Indonesia, dilihat dari segi metode penerjemahan yang digunakan dengan membandingkan makna leksikal dan makna terjemahan. Penelitian VBp dirasa sangat diperlukan karena masih jarang dilakukan apalagi jika dikaitkan dengan penerjemahnya, khususnya dalam novel terjemahan.

\section{METODE}

Penelitian yang digunakan adalah analisis kualitatif dengan pendekatan analisis isi. Sebagaimana telah diketahui bahwa analisis isi merupakan sebuah teknik yang digunakan untuk menganalisis dan memahami teks. Adapun metode yang digunakan peneliti untuk menjawab rumusan masalah yang ditulis yaitu metode deskriptif, studi literatur, dan library research. Metode deskriptif digunakan untuk mengumpulkan data-data yang berkaitan dengan penerjemahan verba berpreposisi dalam terjemahan Novel Alfu Lailah wa Lailah Kisah Raja Syahrayar dan Raja Syahzaman Karya Fuad Syaifuddin Nur. Setelah menentukan verba berpreposisi, kemudian peneliti menjelaskan kecenderungan penerjemahan yang dilakukan penerjemah pada teks tersebut.

Peneliti menjadikan Terjemahan Novel Alfu Lailah wa Lailah Karya Fuad Syaifuddin Nur sebagai sampel penelitian. Hal ini dikarenakan Terjemahan Novel tersebut dianggap paling lengkap dalam menerjemahkan keseluruhan nas dari Novel Alfu Lailah wa Lailah dibandingkan dengan terjemahan novel tersebut dalam bahasa Indonesia yang lainnya.

Adapun objek penelitian ini adalah satu kisah dari Novel tersebut, yaitu kisah Raja Syahrayar dan Raja Syahzaman. Pemilihan ini dilatarbelakangi oleh keterbatasan waktu penulis dan ditemukan adanya variasi penerjemahan di beberapa kalimat yang mengandung VBp pada kisah tersebut.

Sumber data penelitian ini adalah kalimat yang mengandung verba berpreposisi. Kalimat verba berpreposisi tersebut ditinjau dari segi kategori idiom dan non-idiom serta metode penerjemahan yang digunakan.

Sebagaimana diketahui bahwa penelitian ini menggunakan pendekatan analisis isi. Sehingga peneliti akan berhadapan dengan dokumen yaitu novel Alfu Lailah wa Lailah dan terjemahan novel Alfu Lailah wa Lailah Karya Fuad Syaifuddin Nur. Dalam penelitian ini 
yang menjadi instrumen adalah peneliti sendiri yang biasa disebut dengan buman instrument. Alat bantu yang digunakan oleh peneliti adalah kamus dan tabel data untuk menganalisis penerjemahan verba berpreposisi. Berikut ini adalah contoh tabel data yang digunakan dalam penelitian:

Tabel (1) analisis penerjemahan verba berpereposisi.

\begin{tabular}{|l|l|l|l|l|}
\hline No & Data & Terjemahan & VBp & Makna Leksikal \\
\hline & & & & \\
\hline
\end{tabular}

Pada penelitian ini, penulis menggunakan data kalimat yang mengandung verba berpreposisi.Setelah data terkumpul, pada tahap analisis data ini, peneliti secara kualitatif berupaya menangani langsung masalah yang terkandung dalam data. Adapun Prosedur yang digunakan adalah sebagai berikut: (1) mencatat kalimat yang mengandung VBp pada novel Alfu Lailah wa Lailah kisah Raja Syahrayar dan Raja Syahzaman; (2) menganalisis makna leksikal dari VBp dalam kamus; (3) mengklasifikasikan VBp yang jatuh sebagai idiom dan non-idiom; (4) mengidentifikasi penerjemahan kalimat yang mengandung VBp pada novel terjemahan karya Fuad Syaifuddin Nur; (5) menganalisis kecenderungan penerjemahan yang digunakan penerjemah dalam menangani kalimat yang mengandung VBp pada bahasa sumber; (7) Peneliti mencari referensi dari berbagai sumber dan melakukan sintesis lalu membuat simpulan mengacu pada rumusan masalah.

Salah satu cara paling penting dan mudah dalam uji keabsahan hasil penelitian adalah dengan melakukan metode triangulasi. Untuk menguji keabsahan data dalam penelitian ini dilakukan triangulasi dengan teori, hal ini dilakukan dengan mencari teori-teori berbeda yang relevan serta menguraikan pola, hubungan dan menyertakan penjelasan yang muncul dari analisis untuk mencari tema atau penjelasan pembandingan.

\section{HASIL DAN PEMBAHASAN}

\section{Pengklasifikasian VBp}

Pengklasifikasian terhadap VBp ini didasarkan pada perubahan makna yang terjadi dalam verba ketika bergabung dengan preposisi tertentu. Berdasarkan hal tersebut, Aldahesh (2016, p.130) mengklasifikasikan VBp dalam bahasa Arab ke dalam dua kategori; idiom dan non-idiom. Adapun indikator pengklasifikasian tersebut didasarkan pada dua pertanyaan. Hal ini senada dengan Cowie dan Mackin (dalam Aldahesh, 2016, p.13).

The first testing procedure is to ask whether the whole phrase can be substituted by one word. The second testing procedure is

to ask whether the second word (preposition and/or adverb) can be deleted.

\section{a. VBp idiom}

Pada novel Alfu Lialah wa Lailah kisah Raja Syahrayar dan Raja Syahzaman ditemukan VBp yang jatuh sebagai idiom, yaitu sebagai berikut :

\begin{tabular}{|c|c|c|c|}
\hline Data & VBp & $\begin{array}{c}\text { Makna } \\
\text { leksikal }\end{array}$ & $\begin{array}{c}\text { Makna } \\
\text { Idiomatik }\end{array}$ \\
\hline 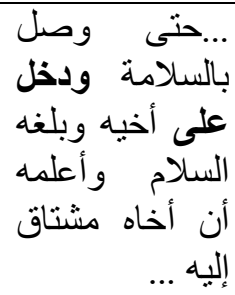 & دلى & $\begin{array}{l}\text { Masuk + } \\
\text { ke }\end{array}$ & $\begin{array}{l}\text { Mengunjungi } \\
\text { menemui }\end{array}$ \\
\hline
\end{tabular}

دخل Pada data di atas terdapat verba yang disertai dengan preposisi على. VBp دخل elasuk ke dalam VBp idiom. Hal ini dikarenakan gabungan verba dan preposisi ini telah memenuhi syarat untuk dinamakan VBp idiom menurut Aldahesh (2016, p.. 14). Pertama, 
Nurmala, Syihabuddin, \& Sopian, Analisis penerjemahan verba berpreposisi...

dua unsur kalimat, yaitu verba دخل memiliki makna leksikal 'masuk' dan preposisi على memiliki makna leksikal 'di atas' dapat disubtitusi menjadi satu kata, yaitu زار (mengunjungi) atau 'menemui' (Mufid, 2010, p. 344). Kedua, preposisi akan mengubah makna verba dalam konteks kalimat tersebut jika dihilangkan. Artinya jika preposisi dihilangkan maka verba دخل akan kembali ke makna leksikalnya sebelum bergabung dengan preposisi yaitu sebagai verba lokatif bermakna 'masuk'. Oleh karena itu jika preposisi dihilangkan maka kalimat di atas menjadi tidak semantis dan tidak gramatikal, karena kehadiran preposisi tersebut juga berfungsi untuk mengubah verba دخل yang asalnya intransitif menjadi verba transitif.

\section{b. VBp Non-Idiom}

Pada novel Alfu Lialah wa Lailab kisah Raja Syahrayar dan Raja Syahzaman ditemukan VBp yang jatuh sebagai non-idiom, yaitu sebagai berikut :

\begin{tabular}{|c|c|c|}
\hline Data & VBp & $\begin{array}{l}\text { Makna } \\
\text { leksikal }\end{array}$ \\
\hline 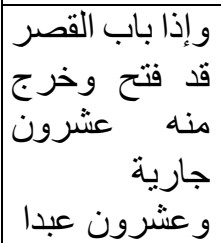 & خ خ من & $\begin{array}{l}\text { Keluar + } \\
\text { dari }\end{array}$ \\
\hline
\end{tabular}

خرج + من Pada data di atas, terdapat VBp , verba ini tergolong pada VBp non- idiom. Hal ini dikarenakan frasa preposisi yang mengikuti verba tersebut tidak memiliki pengaruh pada makna verba jika dihilangkan. Selain itu, gabungan antara verba dan preposisi tersebut dalam konteks ini tidak melahirkan makna baru, melainkan tetap mempertahankan makna leksikal masing-masing. Adapun kemunculan preposisi dalam kalimat ini lebih pada tuntutan verba خرجsebagai verba lokatif.

\section{Kecenderungan Penerjemahan \\ a. Penerjemahan Setia}

Berikut temuan penerjemahan setia yang terdapat dalam novel terjemahan Alfu Lailah wa Lailah kisah Raja Syahrayar dan Raja Syahzaman karya Fuad Syaifuddin Nur.

$$
\text { فرفعت رأسها إلى أعلى الثجرة }
$$

Gadis malang itu menegadabkan kepalanya ke atas pohon ( Nur, 2007, p.. 5)

رفع Berdasarkan data di atas, terdapat VBp رفع + إلى bermakna 'mengangkatkan + ke atas'. Dalam terjemahan, VBp ini telah diterjemahkan dengan tetap memunculkan makna leksikal dari verba dan preposisi sesuai struktur bahasa sumber. Verba disepadankan pada bahasa sasaran sesuai konteks kalimat yaitu menjadi 'menengadahkan'. Hal ini menunjukkan bahwa penerjemah menggunakan makna secara setia.

\section{b. Penerjemahan Semantis}

Berikut temuan penerjemahan semantis yang terdapat dalam novel terjemahan Alfu Lailah wa Lailah kisah Raja Syahrayar dan Raja Syahzaman karya Fuad Syaifuddin Nur.

$$
\text { فلما رأيا ذلك خافا وطلعا إلى أعلى الثجرة }
$$

Melihat sosok hitam itu mendekat, Syahrayar dan Syahzaman merasa amat ketakutan dan segera memanjat pohon. (Nur, 2007, p.. 5)

Dari segi penerjemahan, VBp + طلع إلى secara leksikal bermakna 'memanjat + ke'. Dalam terjemahan, penerjemah hanya memunculkan makna verba sedangkan preposisi dilesapkan. Namun meskipun demikian penerjemah masih cenderung berpihak pada bahasa sasaran. hal ini menunjukkan bahwa penerjemah menggunakan makna secara semantis, yakni terjemahan masih berorientasi pada bahasa sumber namun lebih fleksibel. Adapun terjemahan alternatif yang sesuai dengan konteks kalimat diatas yaitu : ...ia memanjat ke puncak pohon..

\section{c. Penerjemahan Idiomatik}

Berikut temuan penerjemahan idiomatik yang terdapat dalam novel terjemahan Alfu Lailah wa Lailab kisah Raja Syahrayar dan Raja Syahzaman karya Fuad Syaifuddin Nur. 
Jurnal Pendidikan Bahasa dan Sastra, Volume 19, Nomor 1, April 2019, 131-137

طار عقله من رأسه

dia merasa seolab-olah ingatannya telah bilang. ( Nur, 2007, p.4)

Dari segi penerjemahan, $\mathrm{VBp}+$ طار من.Secara leksikal bermakna 'terbang + dari'. Namun pada terjemahan, penerjemah lebih cenderung pada terjemahan idiomatis. Senada dengan Newmark (dalam Syihabuddin, 2016, p.. 63) bahwa penerjemahan idiomatis adalah penerjemahan yang dilakukan dengan mereproduksi pesan bahasa sumber, tetapi cenderung mengubah nuansa makna karena penerjemah menyajikan kolokasi dan idiomidiom yang tidak terdapat dalam nas sumber.

\section{d. Penerjemahan Komunikatif}

Berikut temuan penerjemahan komunikatif yang terdapat dalam novel terjemahan Alfu Lailah wa Lailab kisah Raja Syahrayar dan Raja Syahzaman karya Fuad Syaifuddin Nur.

وقد ملك البلاد وحكم بالعدل بين العباد اسمه الملك شهريار ... Raja Syahrayar adalah seorang penguasa yang adil terbadap rakyatnya (Nur, 2007, p.1)

حكم + ب Dari segi penerjemahan, VBp secara leksikal bermakna 'menetapkan + dengan'. Namun pada terjemahan , VBp tersebut tidak diterjemahkan dengan setia, hal ini menunjukkan bahwa penerjemah hanya menggunakan makna secara komunikatif. Penerjemahan di atas lebih menitikberatkan pada bahasa sasaran. Adapun alternatif lain untuk terjemahan VBp pada konteks kalimat di atas yaitu : ...dan ia menetapkan (perkara) diantara rakyatnya dengan adil..

\section{SIMPULAN}

Berdasarkan hasil penelitian dan pembahasan dapat ditarik kesimpulan bahwasannya dalam kisah Raja Syahrayar dan Raja Syahzaman, terdapat $56 \mathrm{VBp}$ dari jumlah 43 data. Verba yang menyusun struktur VBp tersebut disertai dengan preposisi yang bervariasi. Verba yang berpreposisi dengan preposisi werjumlah 9 kalimat , berpreposisi إلى berjumlah 18 kalimat, berpreposisi عن berjumlah 3 kalimat, berpreposisi على berjumlah 3 kalimat, berpreposisi في berjumlah 4 kalimat, berpreposisi berjumlah 13 kalimat, dan berpreposisi J berjumlah 6 kalimat. Dari sejumlah data tersebut ditemukan $2 \mathrm{VBp}$ idiom dan 54 VBp non-idiom.

Adapun dari segi kecenderungan penerjemahan, ditemukan adanya 4 metode penerjemahan yang digunakan. Dua di antaranya metode yang lebih menekankan pada bahasa sumber, yaitu metode penerjemahan setia dan semantis, dan dua di antaranya metode yang lebih menitik beratkan pada bahasa sasaran yaitu metode idiomatik dan komunikatif. Secara spesifik dari jumlah 43 data yang terdiri dari 56 VBp tersebut terdapat 22 metode penerjemahan setia, 7 penerjemahan semantis, 1 penerjemahan idiomatik, dan 13 penerjemahan komunikatif.

\section{DAFTAR RUJUKAN}

Aldahesh, A. Y. (Aldahesh, A. Y. (2016) . Pinning Down the Phenomenon of Idiomatic Phrasal Verbs in Arabic. International Journal of Language and Linguistics. 3(1), 12-24.

Ali, \& Mudhor. 0446. Kamus Al Ashr. Yogyakarta: Yayasan Ali Maksum.

Catford, J.C. (1965). A Linguistic Theory of Translation: An Essay in Applied Linguistics. Walton Street: Oxford University Press .

Dhyaningrum, A., et al. (2016). Analisis Teknik Penerjemahan dan Kualitas Terjemahan Kalimat yang Mengandung Ungkapan Satire dalam Novel The 100-Year-Old Man Who Climbed Out of The Window and Dissapeared. Prasasti: Journal of Linguistics, 1 (2), 210-229.

Kamalie, S. (2013). Masalah Penerjemahan Kolokasi dalam Tafsir Fi Zilāl al-Qur,ān. Jurnal TS AQAFAH, 9(1), 172-202.

Nur, F. S. (2009). Hikayat 1001 Malam. Jakarta: Qisthi Pers.

Nur, T. (2016). Verba Berpreposisi dalam Bahasa Arab : Analisis Struktur dan Makna. Prosiding Konferensi Nasional Bahasa Arab II, 1-13.

Perdana, D. H (2017). Strategi Penerjemahan Bahasa Arab yang Berterima dan Mudah Dipahami. Jurnal Bahasa Lingua Scientia. 9 (1), 143-160.

Rokib, \& Mudzakkir. (2016). Negosiasi Islam dan Budaya Lokal pada Terjemahan Novel " Kisah Seribu Satu Malam" : Sebuah Kajian Parateks. Ibda, 14 (1), 79090. 
Nurmala, Syihabuddin, \& Sopian, Analisis penerjemahan verba berpreposisi...

Sa'ad, et al. (2015). Fenomena Antara Idiom dan Kolokasi: Satu Analisis Terjemah Struktur dan Makna. Jurnal Linguistik. 19 (2), 10-23

Syihabuddin. (2016). Penerjemahan ArabIndonesia: Teori dan Praktik. Bandung : UPI Press. 